Коваленко С. И., к.э.н., доцент Дунайский институт Национального университета «Одесская морская академия» г. Измаил, Одесская область, Украина

DOI: https://doi.org/10.30525/978-9934-26-064-3-10

\title{
ПРОБЛЕМЫ И ПЕРСПЕКТИВЫ ЕВРОИНТЕГРАЦИИ МОРСКОЙ ОТРАСЛИ УКРАИНЫ
}

\begin{abstract}
Открывшиеся перспективы интеграции украинских портов в транспортную систему Черноморского региона и глобальную мировую транспортную сеть, диктуют необходимость особого внимания к проблеме формирования инновационной системы морского транспорта Украины в соответствии с современными требованиями мирового рынка.

Процесс вхождения Украины в мировую экономическую систему и прежде всего её интеграция на трансграничном уровне в рамках еврорегионов ведёт к росту товарообменных операций между странами ОЧЕС и способствует взаимовыгодному сотрудничеству. Геостратегическое же расположение Украины позволяет ей быть выгодным мостом для транзитных перевозок товаров и пассажиров между государствами Европы, Азии и Ближнего Востока. Трансчерноморские морские перевозки обеспечивают осуществление торговых связей через Черноморский регион, обслуживание внешней торговли и обеспечение взаимовыгодной кооперации стран ОЧЭС через соответствующие порты. Но сегодня, имеет место сокращение валютных поступлений от экспорта транспортных услуг, в том числе по причине значительного снижения грузопотоков по реке Дунай. Экономика еврорегиона «Нижний Дунай» расположенного на перекрёстке важнейших международных путей сообщения из Европы в Азию исторически формировалась за счёт доходов морехозяйственного комплекса, а современные перспективы развития этого «депрессивного региона» во многом определяются потенциалом сетевых структур интегрированных именно в морской кластер [1].
\end{abstract}


Исходя из этого, транспортная система - одна из составляющих успеха и непременных атрибутов современного государства, к которой должны предъявляться высокие требования в отношении качества, регулярности и надежности транспортных связей, сохранности грузов и безопасности перевозки пассажиров, сроков и стоимости доставки. Транзитное положение Украины одна из немногих черт привлекательности национального рынка Украины для зарубежных инвесторов и производителей, поскольку западноевропейские страны не могут не считаться с такой крупной (по размерам и населению) страной, расположенной на перекрёстке торговых путей. Важнейшим фактором усиления роли транспорта во внешнеэкономической деятельности страны есть и трансграничность Украины: она имеет наидлиннейшие границы среди европейских стран. Поскольку в стоимости продукта играет роль транспортная составляющая, естественно, выгоднее налаживать связи с соседями, уменьшая тем самым транспортные расходы и увеличивая прибыль. В данном случае Украина имеет преимущественное положение из-за многочисленности стран-соседей. Из всего вышесказанного следует, что при интеграции в европейскую и мировую экономику потребность в высокоразвитой транспортной системе всё более усиливается, она становится базисом для эффективного вхождения Украины в мировое сообщество и занятия в нём места, отвечающего уровню высокоразвитого государства. Эта тенденция предопределяет параметры производства, инвестиционного процесса и, как следствие, развитие морского транспорта. При этом, последний становится важнейшим условием защиты экономических интересов и оптимизации экспорта транспортных услуг. К числу основных ожидаемых результатов создания морского кластера можно отнести усиление межфирменных потоков идей и информации; обеспечение соответствия стратегий развития отдельных предприятий общей стратегии развития приморского региона и портового хозяйства Украины; активизацию инновационной деятельности в отрасли; решение ряда социальных проблем в регионе; повышение 
квалификации работников предприятий; рост благосостояния региона и уровня конкурентоспособности участников кластера.

Реализация кластерного подхода в рамках приграничного сотрудничества создает большой потенциал экономического роста приграничных областей. Трансграничные кластеры охватывают смежные приграничные территории соседних государств, в состав которых входят институты, размещенные по обе стороны границы. Они в большинстве случаев должны быть результатом реализации региональных стратегий развития трансграничного сотрудничества. И если в странах ЕС трансграничные кластеры действуют в достаточно унифицированном законодательной среде, то на границах Украины они действуют в противоречивом законодательном поле [2].

Одесская область - единственная из приморских регионов, привлечена к деятельности Еврорегиона «Нижний Дунай», активно участвует в пяти европейских трансграничных организациях: Ассамблеи еврорегионов; Ассоциации европейских приграничных регионов; Рабочего содружества придунайских стран; Конференции Приморских регионов Европы; Ассамблеи европейских винодельческих регионов. В начале XXI века регион Черного моря приобретает стратегическое значение, что обусловлено расширением НАТО и Европейского Союза, усилением российского, турецкого и китайского факторов, внедрением европейской политики соседства для большинства черноморских стран и присоединения к ЕС Румынии и Болгарии, развитием торговых отношений между странами, которые размещены на евроазиатских наземных транспортных маршрутах. Это стало основой для создания концепции Большого Черноморского региона (the Wider Black Sea region).

На сегодня в рамках Европейского инструмента соседства и партнерства, который начал действовать с 2007 года, разработан проект создания в бассейне Черного моря Еврорегиона «Черное море», в который войдут Болгария, Греция, Румыния, Украина, Турция, Россия, Грузия, Приднестровский регион Молдовы. Принимая во внимание растущий интерес к трансграничному 
сотрудничеству со стороны ЕС, еврорегион «Черное море» может стать важным инструментом продвижения Украины на пути европейской интеграции. Для организации деятельности субъектов предпринимательской деятельности, направленной на достижение конкретной экономической цели, целесообразно в рамках еврорегиона «Черное море» создать морской трансграничный кластер, который бы охватывал приморские регионы стран Черноморского бассейна.

Термин «морской кластер» («maritime clusters») означает группу фирм, научно-исследовательских институтов и учебных заведений (университетов, специализированных школ и т. д.), иногда пользующихся поддержкой национальных или местных властей, которые сотрудничают с целью внедрения технических новшеств для улучшения деятельности морской отрасли. В Голландии, Норвегии, Италии этот термин трактуется в расширенном смысле и означает комплекс морских видов деятельности, которые переплетаются и взаимодействуют, например, мореплавание, эксплуатация портов, судостроение и судоремонт, рыболовство, морской туризм, оффшорные предприятия и пр. Функционирование логистической сети в рамках трансграничного морского кластера обеспечит оптимальную организацию предприятий транспортного и производственного комплекса на территориальной основе. Как результат фундаментальных изменений вследствие развития мировой экономики, технологий и общества, сфера экономической активности портов вышла за территориальные границы и перенесена на вспомогательные объекты за их пределами в соответствии с требованиями системы комплексных поставок. Такой подход ведет к формированию портовых логистических сетей, охватывающих различные транспортные узлы (например, специализированные порты, терминалы, складские и производственные мощности, промышленные объекты), деятельность которых зависит от грузовой работы крупных портов. Особое внимание следует уделить формированию инновационной модели трансграничной кооперации, которая предусматривает концентрацию 
ресурсов приграничных регионов на проведение фундаментальных и прикладных исследований направленных на развитие их научного, технологического и производственного потенциала, а также использование программно-целевого подхода к реализации инновационных проектов развития Черноморского еврорегиона. Создание и функционирование трансграничного морского кластера в Черноморском регионе обеспечит активизацию экономического сотрудничества и развитие отрасли морского транспорта.

\section{Литература:}

1. Коваленко С.И. Еврорегион «Нижний Дунай»: перспективы развития инновационных форм трансграничной кооперации в условиях расширения ЕС / С.И. Коваленко. Проблемы и перспективы сотрудничества между странами Юго-Восточной Европы в рамках Черноморского экономического сотрудничества и ГУАМ. Сборник научных трудов. Ростов- на-Дону-Донецк : ДонНУ, 2013. C. 203-207.

2. Коваленко С.И. Стратегия трансграничной кооперации ЕС как фактор глобальной экономической безопасности. Міжнародна економічна політика. Спец. випуск. Частина 1: Науковий журнал Київського національного економічного університету імені Вадима Гетьмана. Київ: КНЕУ, 2012. С. 405-411. 